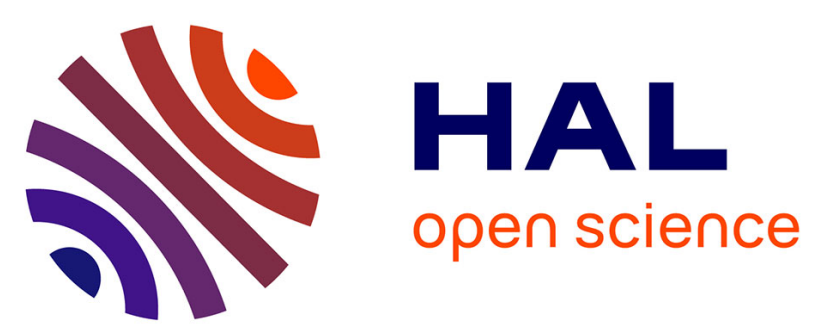

\title{
Albumin infusion improves endothelial function in septic shock patients: a pilot study
}

Geoffroy Hariri, Jérémie Joffre, Stephanie Deryckere, Naïke Bigé, Guillaume

Dumas, Jean-Luc Baudel, Eric Maury, Bertrand Guidet, Hafid Ait-Oufella

\section{- To cite this version:}

Geoffroy Hariri, Jérémie Joffre, Stephanie Deryckere, Naïke Bigé, Guillaume Dumas, et al.. Albumin infusion improves endothelial function in septic shock patients: a pilot study. Intensive Care Medicine, 2018, 44 (5), pp.669-671. 10.1007/s00134-018-5075-2 . hal-01959572

\section{HAL Id: hal-01959572 \\ https://hal.sorbonne-universite.fr/hal-01959572}

Submitted on 18 Dec 2018

HAL is a multi-disciplinary open access archive for the deposit and dissemination of scientific research documents, whether they are published or not. The documents may come from teaching and research institutions in France or abroad, or from public or private research centers.
L'archive ouverte pluridisciplinaire HAL, est destinée au dépôt et à la diffusion de documents scientifiques de niveau recherche, publiés ou non, émanant des établissements d'enseignement et de recherche français ou étrangers, des laboratoires publics ou privés. 


\title{
Albumin infusion improves endothelial function in septic shock patients: a pilot study
}

\author{
Geoffroy Hariri ${ }^{1}$, Jérémie Joffre ${ }^{1,2}$, Stephanie Deryckere ${ }^{1}$, Naïke Bigé ${ }^{\text {, Guillaume Dumas }}{ }^{1}$, Jean-Luc Baudel ${ }^{1}$, \\ Eric Maury ${ }^{1,2,3}$, Bertrand Guidet ${ }^{1,2,3}$ and Hafid Ait-Oufella $a^{1,2,4^{*}}$ (D)
}

\section{Dear Editor,}

Sepsis is a life-threatening condition in response to microbe injury, leading to tissue hypoperfusion, multiorgan failure and death. Human and experimental studies have shown that endothelial dysfunction is involved in microcirculatory blood flow impairment through several mechanisms including vasomotor tone dysregulation, activation of coagulation and glycocalyx damage [1]. Experimental studies suggested that human serum albumin (HSA) could have protective effects on endothelial cells [2], but such a hypothesis has never been directly tested in vivo. The aim of this study was to compare the effect of saline versus HSA bolus infusion on endothelial function in septic shock patients.

\section{Methods}

In our intensive care unit, we prospectively included adult patients admitted for septic shock [3]. Standard patient management was guided by international guidelines [4], including fluid resuscitation $(30 \mathrm{~mL} / \mathrm{kg}$ of crystalloids) and norepinephrine infusion, to achieve a mean arterial pressure $\geq 65 \mathrm{mmHg}$. When additional volume expansion was decided by the physician in charge of the patient within the first $24 \mathrm{~h}$, skin endothelial function was measured before and $1 \mathrm{~h}$ after volume expansion in the forearm area, as previously described (supplemental material) [5]. The patient received either a $500-\mathrm{mL}$ bolus saline or a $100-\mathrm{mL}$ bolus HSA $20 \%$ over 15 min according to physician's decision, based on global hemodynamic parameters and tissue hypoperfusion markers. Decision

\footnotetext{
*Correspondence: hafid.aitoufella@aphp.fr

${ }^{1}$ Assistance Publique-Hôpitaux de Paris (AP-HP), Service de Réanimation Médicale, Hôpital Saint-Antoine, 184 Rue du Faubourg Saint-Antoine, 75571 Paris Cedex 12, France

Full author information is available at the end of the article
}

on the fluid type was made on physician's discretion. Endothelial function measurements were performed only in stabilized patients whose vasopressor dose was unchanged during the last $2 \mathrm{~h}$.

The protocol was approved by our institution's ethical committee, Comité de Protection des Personnes (CPP Saint-Louis, Paris, France). The study required no other specific intervention. Acetylcholine iontophoresis and quantification of endothelial reactivity were performed blindly by a third party. Results were expressed as median (25th-75th percentiles) and quantitative data comparisons used the Mann-Whitney test.

\section{Results}

Thirty-five patients were included during a 4-month period, 3 patients were excluded because of agitation and 2 because of poor non-pulsatile blood flow signal. Among the 30 patients included in the study, 15 received saline and 15 received HSA. Median SAPS II was 42 (3758 ) and median SOFA score was 7 (4-9). The most frequent primary sites of infection were the lungs $(30 \%)$ and the urinary tract (27\%). The average time between ICU admission and inclusion [14 (11-18) versus $12(11-17) \mathrm{h}$; $P=0.96]$, and the infused volume before inclusion $[2500$ $(1500-3500) \mathrm{mL}$ vs $2500(1750-2500) \mathrm{mL} ; P=0.17]$ were not different between groups. Except for age distribution, demographic characteristics and co-morbidities were not different between groups. In addition, hemodynamic parameters and severity scores were similar between groups (Supplemental Table). Skin blood flow, whether at baseline or after fluid infusion, was not different between saline and HSA groups. Before fluid infusion, endothelial response to acetylcholine was not different between groups [AUC 3295 (1148-5938) vs 3082 (879-4902), $P=0.70]$. Interestingly, endothelial reactivity improved 


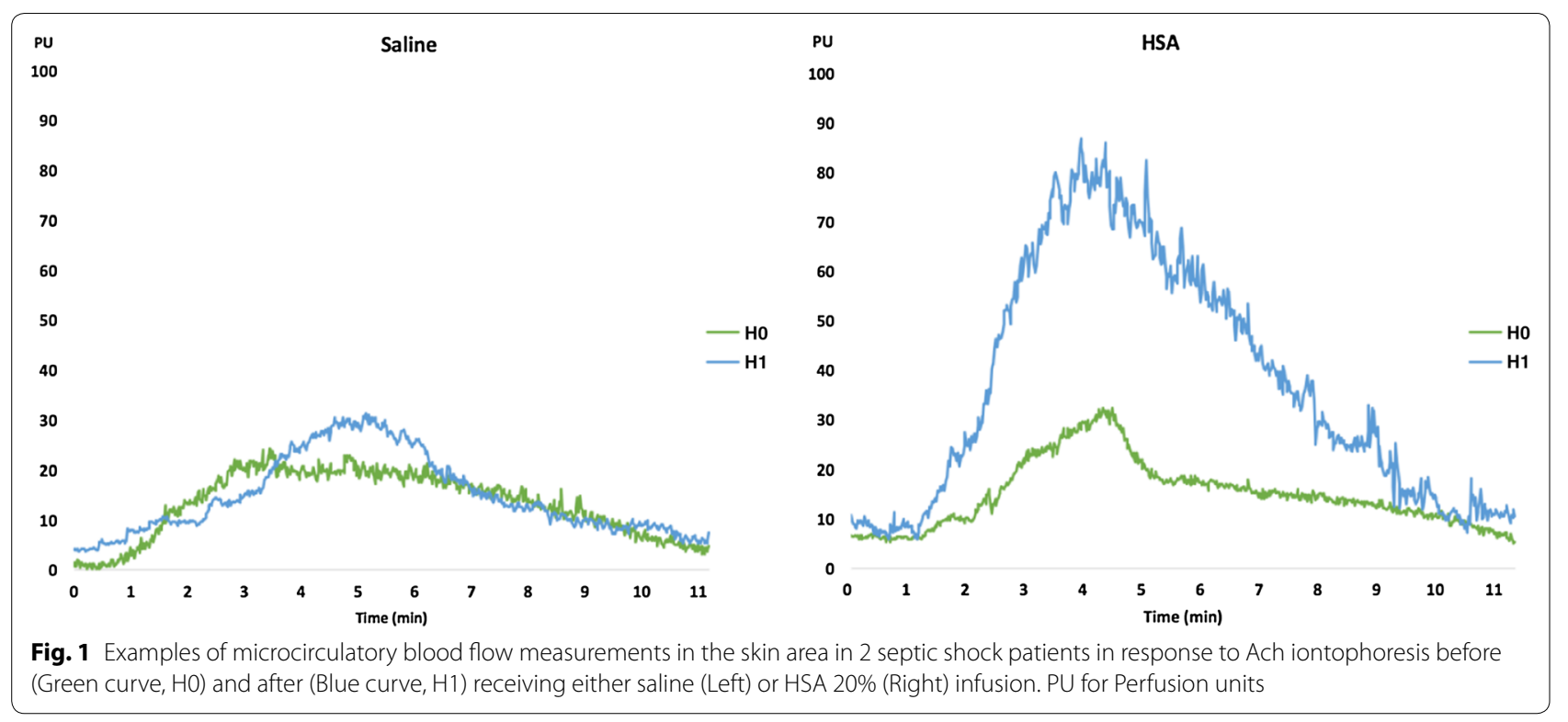

twofold after HSA infusion [AUC 5857 (2888-16679) at $\mathrm{H} 1$ vs $3082(879-4902)$ at $\mathrm{H0}, P=0.04]$, whereas bolus saline infusion had no significant impact on endothelial function [AUC 2388 (1914-10455) at H1 versus 3295 (1148-5938) at HO, $P=$ NS] (Supplemental material), Fig. 1. We did not find any significant correlation between variations of endothelial reactivity between $\mathrm{HO}$ and $\mathrm{H} 1$ and norepinephrine dosages for both groups (supplemental material).

\section{Discussion}

We found for the first time that HSA infusion had beneficial effects on skin endothelial function in septic shock patients. Variations of both cardiac output and skin blood flow were not different between groups, suggesting that the beneficial effects of albumin could be independent of its oncotic properties. Among the mechanisms that could be proposed to explain the vascular protection of albumin, its anti-oxidant properties may be of paramount importance [2]. Our non-randomized study is limited by potential selection bias such as higher bolus volume in the saline group, which might damage glycocalyx. Our results need to be confirmed in a larger randomized trial.

\section{Electronic supplementary materia}

The online version of this article (https://doi.org/10.1007/s00134-018-5075-2) contains supplementary material, which is available to authorized users.

\section{Author details}

${ }^{1}$ Assistance Publique-Hôpitaux de Paris (AP-HP), Service de Réanimation Médicale, Hôpital Saint-Antoine, 184 Rue du Faubourg Saint-Antoine, 75571 Paris Cedex 12, France. ${ }^{2}$ Université Pierre-et-Marie Curie-Paris 6, Paris, France. ${ }^{3}$ Inserm U1136, 75012 Paris, France. ${ }^{4}$ Inserm U970, Centre de Recherche Cardiovasculaire de Paris (PARCC), Paris, France.

\section{Author contributions}

Study concept and design, all authors. Acquisitions of data, GH, JJ, SD, NB, JLB, and HAO. Drafting of the manuscript, GH, JJ, GD, HAO, EM and BG. Critical revision of manuscript, all authors. Statistical analysis, GH and HAO.

\section{Compliance with ethical standards}

\section{Conflicts of interest}

B. Guidet has received honorium from LFB biomedicaments and Grifols.

\section{References}

1. Ait-Oufella H, Maury E, Lehoux S, Guidet B, Offenstadt G (2010) The endothelium: physiological functions and role in microcirculatory failure during severe sepsis. Intensive Care Med 36(8):1286-1298. https://doi. org/10.1007/s00134-010-1893-6

2. Taverna M, Marie AL, Mira JP, Guidet B (2013) Specific antioxidant properties of human serum albumin. Ann Intensive Care 3(1):4. https://doi. org/10.1186/2110-5820-3-4

3. Singer M, Deutschman CS, Seymour CW, Shankar-Hari M, Annane D, Bauer M, Bellomo R, Bernard GR, Chiche JD, Coopersmith CM, Hotchkiss RS, Levy MM, Marshall JC, Martin GS, Opal SM, Rubenfeld GD, van der Poll T, Vincent JL, Angus DC (2016) The third international consensus definitions for sepsis and septic shock (sepsis-3). JAMA 315(8):801-810. https:// doi.org/10.1001/jama.2016.0287

4. Rhodes A, Evans LE, Alhazzani W, Levy MM, Antonelli M, Ferrer R, Kumar A, Sevransky JE, Sprung CL, Nunnally ME, Rochwerg B, Rubenfeld GD, Angus DC, Annane D, Beale RJ, Bellinghan GJ, Bernard GR, Chiche JD, Coopersmith C, De Backer DP, French CJ, Fujishima S, Gerlach H, Hidalgo JL, Hollenberg SM, Jones AE, Karnad DR, Kleinpell RM, Koh Y, Lisboa TC, Machado FR, Marini JJ, Marshall JC, Mazuski JE, McIntyre LA, McLean AS, Mehta S, Moreno RP, Myburgh J, Navalesi P, Nishida O, Osborn TM, Perner A, Plunkett CM, Ranieri M, Schorr CA, Seckel MA, Seymour CW, Shieh L, Shukri KA, Simpson SQ, Singer M, Thompson BT, Townsend SR, Van der Poll T, Vincent JL, Wiersinga WJ, Zimmerman JL, Dellinger RP (2016) Surviving sepsis campaign: 
international guidelines for management of sepsis and septic shock. Intensive Care Med 39(2):165-228. https://doi.org/10.1007/ s00134-012-2769-8

5. Bourcier S, Joffre J, Dubee V, Preda G, Baudel JL, Bige N, Leblanc G, Levy Bl, Guidet B, Maury E, Ait-Oufella H (2017) Marked regional endothelial dysfunction in mottled skin area in patients with severe infections. Crit Care 21(1):155. https://doi.org/10.1186/s13054-017-1742-x 